The Inheritors, H. G. Wells and Science Fiction: The Dimensions of the Future

On 20 November 1901, Wells wrote to his agent, J. B. Pinker, revealing that "Conrad came along today with Anticipations on the train. He doesn't like it in a friendly \& respectful way \& would like very much to go for it in two or three articles." Anticipations, Wells first non-fiction book, published as a volume earlier that month in Fortnightly Review, set out, among other things, Wells's radical ideas for how to secure the future of humanity. Looking back over his career in Experiment in Autobiography (1934), Wells writes: "Now Anticipations was not only a new start for me, but, it presently became clear, a new thing in general thought" (645). This "new thing" contained such extraordinary and revolutionary proposals that it propelled Wells to Edwardian literary superstardom. The book was an immediate bestseller, and by mid-December 1901 Wells was urging Pinker to bring it out as a cheap paperback. ${ }^{2}$

In June of the same year William Heinemann had published the second collaborative effort of Joseph Conrad and Ford Madox Ford, The Inheritors: An Extravagant Story. ${ }^{3}$ The novel plays with the Wellsian notion that fantastical events might effect a political and social transformation of Britain's very near future. Yet, unlike their friend Wells, who had begun to promote the potential for humanity to progress and to improve, to evolve into higher beings, Conrad and Ford envisioned an apocalyptic dystopia where humanity would be swept away by a race of people from a fourth dimension, the Inheritors of the title. The world promised by these Inheritors is ruled by a calculating, ascetic political class whose hyper-rational values and 
beliefs are poised to supersede Victorian sensibility, sensitivity and, what they regard as sentimentality.

As Max Saunders argues, the unnamed Fourth Dimensionist woman in The Inheritors is "a personification of very much that new rejection of any traditions of piety, altruism or restraint": "The novel poses its present—-the present of the Boer War-as a crisis; the turn-of-the-century as a turning point" ("Empire of the Future" 132 and 126). Robert Hampson elaborates on this when he asserts that in The Inheritors, this turning point pivots on "the replacement of 'probity' and 'altruism' of the old-style Toryism by the new Toryism of Joseph Chamberlain, and the replacement of 'oldfashioned small enterprises' by ruthless individualism and the 'gigantic trusts' of monopoly capitalism" (68). The Inheritors is thus, in many ways, a "condition of England" novel, a timely, but flawed, meditation on Britain's social and cultural values as the new century dawns. In both fiction and non-fiction respectively, therefore, Conrad and Ford, and their close neighbor H. G. Wells explore the direction humanity would take in the twentieth century. It is almost inconceivable that the three authors did not discuss these ideas during their regular visits to each other; but, as Wells's letter to Pinker proves, Conrad was not as enthusiastic as the general public about Wells's propositions.

The impact on The Inheritors of Wells's ideas about the future will be the main focus of this paper. Along the way, it will also unearth the traces of Wells's scientific writings inscribed in The Inheritors, demonstrating that Conrad and Ford were actively drawing on their friend's extraordinary imagination to create their own tale of a fantastic near future. However, the inevitable conclusion is that Conrad and Ford had a very different idea of what constitutes "progress," and that their novel in 
many ways represents a critique and rebuttal of some of Wells's more radical utopian visions as expressed in Anticipations. ${ }^{4}$

\section{The Fourth Dimension}

The idea of a fourth dimensional space was first articulated by Joseph-Louis Lagrange, an Italian mathematician and astronomer, in the eighteenth century. This idea of an unseen, undetected and undetectable spatial dimension to the universe began to take hold of the literary imagination in the nineteenth century; and thus in his Introduction to The Inheritors David Seed confirms that following the publication of “Edwin A. Abbott's Flatland in 1884 and C. H. Hinton's Scientific Romances (188486), the term 'fourth dimension' had become sufficiently familiar as not to warrant explanation in itself" (xxii). ${ }^{5}$ Nearly a decade later the possibility of a fourth dimension still mesmerised the general public. In 1893 W. T. Stead, journalist and champion of the occult, wrote: "We are on the eve of the Fourth Dimension; that is what it is!". ${ }^{6}$ Stead's excitement is evidence of what Will Tattersdill describes as "the suggestion that we are on the verge of achieving some great new understanding about the universe, only previously hinted at" (94-5). And indeed, only three years later came the announcement of the discovery of X-rays, a scientific breakthrough that seemed to promise proof of other dimensions, of hidden worlds and alternative universes.

Saunders observes that the turn-of-the-century was a time "notoriously beset with anxiety about the changes the future might bring"; and thus The Inheritors was written against the backdrop of a "surge of futurological fiction" from the likes of William Morris and H. G. Wells, both of whom used the idea of dimensional travel to probe possible futures ("Empire of the Future" 131). ${ }^{7}$ This was also a moment when 
significant scientific and technological discoveries and advances were being made, and The Inheritors displays a keen consciousness of this zeitgeist, most notably in its use of the possibilities unleashed by the discovery of X-rays and discussions about the possibilities of a fourth spatial dimension. The result is a novel that, in the words of Elaine L. Kleiner, "is an early attempt to codify the form one can now safely label 'science fiction'" (26). ${ }^{8}$

The fourth dimension is used in literature to explore the possibility of utopias, of potential futures and the idea of parallel universes inhabited by beings like ourselves, but with differing values and morals. This is made clear very early on in The Inheritors when the woman from the Fourth Dimension entraps the central character, Etchingham Granger, and reveals another plane of existence, beyond the very tangible, very visible Bell Harry Tower of Canterbury Cathedral:

One seemed to see something beyond, something vaster-vaster than cathedrals, vaster than the conception of the gods to whom cathedrals were raised. The tower reeled out of the perpendicular. One saw beyond it, not roofs, or smoke, or hills, but an unrealized, an unrealizable infinity of space. It was merely momentary. The tower filled its space again and I looked at her. (8)

The idea of a fourth dimension is absolutely crucial to the central aim of Conrad and Ford's novel: an exploration of the values and beliefs that a humane society must adhere to in the face of progress.

"The First Idea": The Inheritors and H. G. Wells 
Neither Conrad nor Ford had considered writing scientific fantasies before embarking on The Inheritors, but they were both awed by the imaginative audacity of Wells's writing, and Ford confirms that The Invisible Man (1897), The Sea Lady (1901), "and two short stories called, the one The Man Who Could Work Miracles and the other Fear, made up at that date all the English writing that, acting as it were as a junta, we absolutely admired" (A Personal Remembrance 43). ${ }^{9}$ Ford's primary consideration in singling out these stories is form and expression, but, like .Conrad, he was also impressed by Wells's imagination, as were many of their contemporaries. ${ }^{10}$ Indeed, Michael Sherborne notes that by the turn of the century Wells had become, despite his relative youth, a kind of figurehead for authors seeking new forms of literary expression:

The south coast was home to several authors who did not fit naturally into the British Establishment and who found it agreeable to position themselves some distance from London and enjoy each other's mutual support, perhaps even reciprocal altruism. Ford Madox Hueffer later claimed that all the literary artists in England lived in a three-to-five-mile radius of Wells's house, looking up to him because of his "immense sales, and the gift of leadership". (138) $)^{11}$

Conrad and Ford were two such authors and Wells's proximity inevitably had an impact on The Inheritors, as an early reviewer for the Daily Mail on 19 July 1901 confirms: "It is interesting to learn that Mr. Conrad and Mr. Hueffer got the first idea of their book from a striking sentence of Mr. H. G. Wells [...]" (in The Inheritors 158). Writing to his agent, J. B. Pinker, just five days before this review, Conrad 
reveals, "There's a Daily Mail man coming to see me on Tuesday,” confirming Conrad as the source of this account of "the first idea." (Collected Letters 2: 341). Saunders is clear that the fourth dimension element of the book was not there in the original manuscript, speculating that Conrad may have "contributed the scientific notion" of another spatial dimension in The Inheritors (A Dual Life 118). Saunders notes that by 6 October 1899 "Ford had written enough of The Inheritors to try it out Commented [CD1]: Cut made because the information is not necessary to the argument and covers familiar ground. on Conrad: he drove over to the Pent 'with the manuscript of the opening chapters of the novel rather shyly in his pocket," and confirms that "as with 'Seraphina,' the suggestion of collaborating had come from Conrad" (A Dual Life 120). ${ }^{12}$ According to Ford, on reading the first chapter, Conrad declared: "What the devil is this? It is très, très, très chic! It is épatant. That's magnificent" (A Personal Remembrance 133). Conrad was instantly struck by the modernity of Ford's subject matter, but he saw further potential in the material he had in hand. As Kleiner says, science fiction "is a 'mythologic' rather than a 'mimetic' literature in the sense that its subject matter involves the confrontation of human imagination with the unknown rather than the known" (26). Adding the concept of a fourth dimension thus transformed Ford's "mimetic" tale into one that was "mythologic" and thus, as Kleiner claims, Conrad was indeed involved in the emergence of the science fiction genre. ${ }^{13}$

Conrad and Ford's concept of beings from a fourth dimension resonates with the scientific advances and spiritualist speculations of the fin-de-siècle that were fuelling scientific fantasies, such as those of Wells. For, as Wells himself says of The Time Machine (1895): “The idea of treating time as a fourth dimension was, I think, due to an original impulse; I do not remember picking that up. But I may have picked it up, because it was in the air" (Autobigraphy 645). And of course Wells was ever alert to futuristic possibilities, stating that in 1899 he "was already beginning to 
realize there might be better guessing about the trend of things" (Autobiography 645). As a result he wrote Anticipations, a text that predicted the future of politics, society and technology and "which sold as well as a novel" (Autobiography 646).

Conrad and Ford were also influenced by this zeitgeist dominated by concepts of the future and used these for their first published collaboration. The science fiction credentials of The Inheritors lie in its use of the idea of a fourth dimension, clearly a Wellsian influence. In The Time Machine the Traveller asserts: "There is no difference between Time and any of the three dimensions of Space except that our consciousness moves along it" (8 [italics in the original]), and it is possible that this was the sentence that prompted "the first idea". Time, in Wells's sense, constitutes the fourth dimension, after the three dimensions. However, Kleiner argues that Conrad and Ford conceived of the fourth dimension as different to that of Wells:

Breaking with Wells's geometric model of the future extended like a line continuous from the present, Conrad and Ford chose to imagine the future somewhat like a kernel contained within the seed of the present, co-existing with the present as an alternative universe on a different plane in time, its inhabitants gradually, over time, attaining dominance over present forms of life. (29)

In fact other Wells tales, like "The Plattner Story” (1896) and "The Crystal Egg" (1897), had previously presented the concept of universes within universes that Kleiner notices in The Inheritors. It could be argued that Conrad's and Ford's debt to Wells operates on more than one level: their beings from the fourth dimension are also the "inheritors" of Wells's fertile imagination, early science fiction creations.
Commented [CD2]: Unclear - is this a misquotation or are we missing something contextually?

Commented [LD3]: Not a misquotation-not sure what the problem is here....the next sentence contextualizes this? 
Thus, while Conrad and Ford lacked Wells's scientific training, his agile stylistic simplicity, and his fearless self-belief, they were genuinely excited by the vivacity and unique subject matter of Wells's writing; and this inspired them to attempt their own fantastic tale, one that Conrad, on receiving the manuscript in early 1900 , described to Ford as "remarkably weird as a whole" (Collected Letters 2: 234). ${ }^{14}$ However, there are further, possibly even more fascinating correspondences with Wells that can be traced in The Inheritors.

\section{$X$-rays, Science Fiction and The Invisible Man}

In the autumn of 1898 , worried about financial security, Conrad travelled to Glasgow in search of a ship to command. While there he visited Dr. John Macintyre, an early radiologist, and had an X-ray of his hand. Over dinner the conversation turned to speculation about multiple universes, as he details in a letter to Edward Garnett on 29 September 1898:

The secret of the universe is in the existence of horizontal waves whose varied vibrations are at the bottom of all states of consciousness. If the waves were vertical the universe would be different. This is a truism. But, don't you see, there is nothing in the world to prevent the simultaneous existence of vertical waves, of waves at any angles; in fact there are mathematical reasons for believing that such waves do exist. Therefore it follows that two universes may exist in the same place and in the same time - and not only two universes but an infinity of different universes [...]. (Collected Letters 2: 94-5) 
Conrad's excitement reveals a genuine intellectual engagement and fascination with extra dimensional possibilities_ — as Wells says, "it was in the air." Following Röntgen's discovery of X-rays in November 1895 news spread fast, reaching "the English press in the pages of Nature on 23 January, 1896" (Tattersdill 95). Anyone who had read The Time Machine would have felt that life was imitating art. X-rays, by making the flesh and viscera transparent, and revealing the body's osseous matter, proved that science could demystify magic. It took no great imaginative leap to move to the possibility of unveiling other dimensions. And, as Tattersdill argues, a "key characteristic of X-rays" for the general public in the immediate aftermath of their discovery was that "they were as well explained by the spiritualists as by the scientists": "To those who had been discussing spirit photography, invisible light, and worlds beyond human perception for years, the discovery would have seemed a valorisation rather than a surprise" (96). Indeed, in 1896, in his journal of psychical research, Borderland, Stead had speculated that the discovery of X-rays could actually lead to the possibility of a kind of mind-reading: "The presentation of our bones, or the matter of our brain, or the action of the heart, by the ' $X$ ' rays would be far transcended in importance, if it were once established that we could procure a permanent record of our passing moods and fancies." 15 In the midst of such feverish imaginings the authors of The Inheritors must have felt that their fourth dimensionists were very much of the moment.

In his letter to Garnett about X rays Conrad describes the Scottish author Neil Munro, who was among their party in Glasgow: “[he] stood in front of the Röntgen machine and on the screen behind we contemplated his backbone and his ribs. The rest of that promising youth was too diaphanous to be visible" (Collected Letters 2:
Commented [CD4]: Do we need a reference here?

Commented [LD5]: This is a reference back to a quotation by Wells on page 6 . 
95). Griffin, Wells's invisible man, describes the process of becoming transparent thus:

I shall never forget that dawn, and the strange horror of seeing that my hands had become as clouded glass, and watching them grow clearer and thinner as the day went by, until at last I could see the sickly disorder of my room through them, though I closed my transparent eyelids. My limbs became glassy, the bones and arteries faded, vanished, and the little white nerves went last. I gritted my teeth and stayed there to the end. At last only the dead tips of the fingernails remained, pallid and white, and the brown stain of some acid upon my fingers. (Invisible Man 181-82)

Griffin explicitly denies that his process uses "these Röntgen vibrations", but he does reveal that it involves "two radiating centres of a sort of ethereal vibration," giving the invisibility process a scientific basis (172). Drawing on the X-ray, Wells fabricated a plausible explanation of the science behind this invisibility, exploiting a contemporary sensation to create the imaginatively brilliant scientific fantasy that had so impressed Conrad and Ford. Witnessing the effect of the X-ray on Munro, Conrad could not have failed to draw parallels with The Invisible Man, and no doubt reflected on how Wells had used an actual scientific discovery to create a fictional tour de force.

As Wells acknowledged, he had an astonishing ability to conjure stories about ordinary human beings in extraordinary situations: in this respect The Invisible Man is one of the most successful of his literary endeavours. ${ }^{16}$ This creative facility was central to his narrative strategy, as he explains in respect of The Time Machine in Experiment in Autobiography (1934): "I had realised that the more impossible the 
story I had to tell, the more ordinary must be the setting, and the circumstances in which I now set the Time Traveller were all that I could imagine of solid uppermiddle-class comfort" (516). The use of "ordinary" settings for extraordinary occurences is one of Wells's most successful narrative devices, and it is a strategy that Conrad and Ford adopted when they planted their Fourth Dimensionists directly into Edwardian British society. Whether it be on the streets of London, or in the drawing rooms of literary figures, or on the hillsides of Canterbury overlooking the cathedral, their beings from another spatial dimension aim to infiltrate the everyday, and confront the ordinary with the extraordinary.

The Inheritors and H. G. Wells: Time Present and Time Future

Granger's uncanny vision of Canterbury Cathedral at the beginning of The Inheritors involves a metaphorical sweeping away of all the monolithic structures and beliefs that have gone before, including, and perhaps especially, religious faith. As Saunders says, the woman's “ability to make Granger feel she has destabilized Canterbury Cathedral shows the power she represents over feudalism and the church, and faith in either" ("Empire of the Future" 133). The choice of Bell Harry Tower is symbolic: as the Dimensionists abolish human history, treating religions as mere totems, a new world order will emerge to eclipse the old.

In this opening sequence the authors directly challenge Wells's vision for the twentieth century as he was laying it out in Anticipations. On July 7, 1901, in a letter to Elizabeth Healy, Wells explains his prospectus for the book: it was "designed to undermine and destroy the monarch, monogamy, faith in God \& respectability— \& the British Empire, all under the guise of a speculation about motor cars \& electrical heating" (Correspondence 1: 379). The impending end of Victoria's reign and the 
dawn of a new century had caused much uneasy speculation, but for Wells it was an exciting opportunity, as Sherborne argues: "Wells sensed that the new century would be a contrasting age of instability, and he was eager to plunge into the flux" (147).

With The Inheritors, Conrad and Ford also plunged into the uncertainty presented by a new century, but they countered Wells's optimistic prophesies with the chilling portentousness of the intentions of their Fourth Dimensionists.

The woman tells Granger that she comes from "the Fourth Dimension," a spatial plane once inhabited by his own forbears:

"Your"- she used the word as signifying, I suppose, the inhabitants of the country, or the populations of the earth-“your ancestors were mine, but long ago you were crowded out of the Dimension as we are to-day, you overran the earth as we shall do to-morrow. But you contracted diseases, as we shall contract them, — beliefs, traditions; fears; ideas of pity . . . of love. You grew luxurious in the worship of your ideals, and sorrowful; you solaced yourself with creeds, with arts-you have forgotten!” (10)

The woman's assessment of fin-de-siècle Britain as having grown "luxurious in the worship" of its ideals is a scornful reprimand to what the Fourth Dimensionists regard as humanity's "weakness" for religions and culture. She insinuates that humanity's decadence and self-indulgence have eclipsed the ascetic, hyper-rational approach to human affairs of their fourth dimensional forebears.

In a similar vein, at the end of the novel the woman explains her purpose to Granger in bald terms: "I had to sound the knell of the old order; of your virtues, of your honours, of your faiths, of . . of altruism, if you like" (153). Art, human 
compassion, religious faith, romance: these are the concerns and attributes of the lateVictorians that both Wells in Anticipations and Conrad and Ford's Dimensionists seek to obliterate as though to purify or rationalize the world. George Hay speculates that the woman's words "could have come straight from the lips of Ayn Rand" (The Inheritors viii). Yet, her words also echo those of Nietzsche and the apocalyptic writings of the Bible, and thus whilst the Fourth Dimensionalist woman presents herself as a prophet, Granger is unmoved. For him it is like "listening to a parody of a scientific work recited by a phonograph" (9). The sterile distance invoked by the simile compounds the emotionless logic of the woman making her seem robotic, mechanistic.

By the time Conrad and Ford were writing The Inheritors in 1900, apart from The First Men in the Moon (1901), and The Food of the Gods (1904), the best of Wells's science fiction writing was behind him. In Experiment in Autobiography he pinpoints the moment that he turned to discursive works prophesying the future: "Along came the end of the century, just apt to my thoughts, and I arranged [...] to publish a series of papers discussing what was likely to happen in the new century" (645). These papers were to become Anticipations. Wells's attention now was on how to secure humanity's future, and how to ensure that future generations were biologically and intellectually "fit" for their environment, capable of physically evolving in line with Darwinian theories: later he even imagined the now uncomfortable possibility of the emergence of the Samurais of A Modern Utopia (1905). At the very moment that Conrad and Ford were writing an apocalyptic tale in which a super race threatened to eradicate humanity, Wells was arguing in Anticipations that humanity's very endurance was reliant upon its biological ability to evolve into just such a super race. 
In The Food of the Gods Wells envisages the emergence of a race of giants, born out of a spectacularly disastrous attempt to create a "super food". The book ends with the giants' leader, Cossar, striking a heroic and defiant pose, "standing out gigantic with hand upraised against the sky":

For one instant he shone, looking up fearlessly into the starry deeps, mailclad, young and strong, resolute and still. Then the light had passed, and he was no more than a great black outline against the starry sky - a great black outline that threatened with one mighty gesture the firmament of heaven and all its multitude of stars. (317)

This recalls an image that Wells had used earlier in what he had hoped was a politically and scientifically visionary lecture, The Discovery of the Future, delivered at the Royal Institute, in 1902 and quickly published the same year. Wells ends this prophetic work by suggesting that humankind could evolve beyond its physical and earthly boundaries: "All this world is heavy with the promise of greater things, and a day will come $[\ldots]$ when beings, beings who are now latent in our thoughts and hidden in our loins, shall stand upon this earth as one stands upon a footstool, and shall laugh, and reach out their hands amid the stars" (94-5). For Wells, the future of humanity involves a search for a new space within which to develop, evolve and improve. In Discovery of the Future and The Food of the Gods Wells argues that we need not be bound to the earth by our current physical form, that in the future we could attain to beings that are transcendent, beings that could defy the laws of gravity and find new and unforeseen possibilities in the spaces of the starry heavens.

Biologically, this was about as far fetched an idea as Stead's belief in the possibilities 
of spiritualism. The last hundred years have nevertheless shown that humanity's endeavor to reach the stars may not be as far-fetched.

By introducing the cold, emotionless and callously logical Fourth Dimensionists as the beings who will shape our future, Conrad and Wells pose moral questions about whether efficiency and pragmatics should be the primary considerations in terms of progress. Wells's assessment of his present Edwardian times is of a Britain mired in tradition, shackled to its history, and lacking the moral courage and intellectual muscle to challenge assumptions about social, political and religious truths. This, too, is the premise of the Inheritors in Conrad and Ford's novel, but its authors tackle these issues from the opposite moral position: their concern is that the Inheritors do have the capacity to challenge the status quo and manipulate the future. In one sense the Inheritors are exactly the beings that Wells imagines in Anticipations, a race that will eradicate Britain's long established traditions and culture and install a narrow, sterile populism. It is this prospect that dismays Conrad and Ford: they foresee apocalypse where Wells prophesies progress and transcendence.

The woman from the fourth dimension, with whom Granger becomes infatuated, describes the Inheritors' intentions:

I heard the nature of the Fourth Dimension-heard that it was an inhabited plane - invisible to our eyes, but omnipresent [...] I heard the Dimensionists described; a race clear-sighted, eminently practical, incredible; with no ideals, prejudices, or remorse; with no feeling for art and no reverence for life; free from any ethical tradition; callous to pain, weakness, suffering and death, as if they had been invulnerable and immortal. (9-10) 
The inhabitants of the fourth dimension consider themselves superior to common, earthbound mortals. Here, rationality prevails and morality is redundant; all approaches to life in this space are governed by issues of practicality and efficiency. In the new utopia that Wells envisions in Anticipations, efficiency is paramount, and progress is dependent upon human evolution. As with the Inheritors, "The men of the new republic will not be squeamish either in facing or inflicting death.” The humanity of the future "will have an ideal that will make killing worth the while; like Abraham, they will have the faith to kill, and they will have no superstitions about death." ${ }^{17}$ As Wells had said to Elizabeth Healy, part of his intention in Anticipations was to "undermine and destroy" faith in God, and thus the approach to life and death of the people of the new order will be without sentiment and without compassion. The attitude of these people will be strictly utilitarian: "They will naturally regard the modest suicide of incurably melancholy or diseased or helpless persons as a high duty rather than a crime". Capital punishment, Wells argues, will be more expedient and humane than a life in prison. When it comes to non-European peoples Wells is even more unflinchingly "practical". Of the "swarms of black and brown and dirty-white and yellow people, who do not come into the new needs of efficiency," he says, "I take it they will have to go," because the world is not "a charitable institution" (324$5)$.

In an uncompromising application of social-Darwinism, Wells argues that the fault lies in these peoples' inability to adapt to the emerging new world: "So far as they fail to develop sane, vigorous, and distinctive personalities for the great world of the future, it is their portion to die out and disappear" (342). This is strong, distasteful, and unpalatable stuff. However, as Warren Wager points out, “To Wells's credit, he would soon abandon such thoughts"; and Sherborne confirms that within two years 
"Wells would be arguing against negative eugenics; within three defending black people against race prejudice; within four advocating the desirability of a multitracial society" (Wagar 90-91; Sherborne 152). For Sherborne, Anticipations is "both the starting point and the lowest point in Wells's career as a social thinker" (151-52). Provocative and driven by utilitarian considerations, the book marks a pivotal moment in Wells's career both as a novelist and as an influential public figure.

Anticipations was serialized in the Fortnightly Review between April and December 1901, and published in book form in November 1901. The Inheritors was published in June 1901. It therefore follows that neither Conrad nor Ford could have written The Inheritors as a response to Anticipations, but they will have had many discussions with Wells on the ideas contained therein, given that all three met up on a very regular basis in this period. ${ }^{18}$ Indeed, it is almost certain that Conrad and Ford were incorporating concepts that they picked up in discussions with Wells, for the Inheritors are, in so many ways, the fictional embodiment of Wells's ideas in Anticipations. Wells's response to the challenges and possibilities of his own time are pragmatic, functional and, on the surface of it, rational, replete with an optimism born of his scientific background. His ideas are also a response to the possibilities offered by a new century and a new monarch. Deliberately or not, Conrad and Ford's novel is a rebuttal of some of the more outlandish pronouncements in Anticipations, a book that Wells maintains "can be considered as the keystone to the main arch of my work" (Autobiography 643). It is not surprising that he later labeled The Inheritors a 'dead, witless book', and lampooned the novel, Ford, and Conrad mercilessly in The Bulpington of Blup (1932), possibly out of an enduring sense of pique at its critique of his own ideas (Correspondence 3: 38). ${ }^{19}$ 
The fact that on its publication Conrad took exception to Anticipations and wanted to pen an article in response to it is further proof of the conflicting ideas that defined the widening intellectual and philosophical gulf between the two writers. The article was never written, but the previously unpublished letter quoted at the start of this paper adds more weight to the well-known comment by Hugh Walpole that on their last meeting Conrad had said: “The difference between us, Wells, is fundamental. You don't care for humanity but think they are to be improved. I love humanity but know they are not" (Hart Davies168). And their differences did not just lie in their perceptions of humanity itself: humanity's legacy was a further point of divergence.

\section{Throwing away "the treasure of [the] past"}

The premise of both The War of the Worlds and The Inheritors is invasion. Conrad and Ford's Fourth Dimensionists will eradicate what they regard as decadent humanity:

The Dimensionists were to come in swarms, to materialize, to devour like locusts, to be all the more irresistible because indistinguishable. They were to come like snow in the night: in the morning one would look out and find the world white; they were to come as the gray hairs come, to sap the strength of us as the years sap the strength of the muscles. As to methods, we should be treated as we ourselves treat the inferior races. There would be no fighting, no killing; we — our whole social system—would break as a beam snaps, because we were worm-eaten with altruism and ethics. (The Inheritors 12) 
As Kleiner says: "The collaborators hypothesized, much as Bulwer Lytton had in The Coming Race (1871), that evolution was to be imagined not as orderly progression but rather as a process of 'weeding out' and exterminating unsuccessful life forms to make way for the dominance of existing stronger ones" (Kleiner 29). Against the voracity of locusts and the muffling pervasiveness of a blizzard, resistance is futile. In the face of such an implacable, determined invasion humanity would be stripped of its life-affirming attributes, would wither and die in a bloodless, but nonetheless deadly, coup. One is reminded of the Martians' merciless destruction of the Home Counties in The War of the Worlds. The Inheritors come like snow in the night, muffling the existing world, while the Martians, similarly, spread their silent, black vapour like a deadly suffocating blanket: "the swiftly spreading coils and bellyings of that blackness advancing headlong, towering heavenward, turning the twilight to a palpable darkness, a strange and horrible antagonist of vapour striding upon its victims $[\ldots]$ and the swift broadening out of the opaque cone of smoke" (War of the Worlds 148-49). Like Wells and others before them, Conrad and Ford use the potential future extermination of humanity to challenge the complacency of the present and to warn about the future.

Thus, when Granger realizes the enormity of the changes that the Dimensionists are initiating, he has another terrifying visionary moment of a different spatial dimension, this time on the streets of London:

The sheer faces of the enormous buildings near at hand seemed to topple forwards like cliffs in an earthquake, and for an instant I saw beyond them into unknown depths that I had seen into before. It was as if the shadow of annihilation had passed over them beneath the sunshine. (143) 
This sense of the rending of the traditional fabric of British life also finds expression in Wells's aspirational ideas and utopian solutions in Anticipations, but to very different purpose. Wells believed that revolutionary change was necessary and inevitable: for him it was part of the relentless evolutionary pattern of the universe. By contrast, in conceiving their Fourth Dimensionists, Conrad and Ford warned that tackling the complex problems faced by the citizens of a new century required a respect for, and acknowledgement of the interwoven fabric of the past, present and future, rather than a wholesale disposal of all that has gone before. For, as Conrad has Marlow say in Heart of Darkness: "the mind of man is capable of anything - because everything is in it, all the past as well as all the future" (38). The continuity and contingency that Conrad implies here is exactly what is threatened by the Inheritors. In his letter to The New York Times of 2 August 1901, where he defends The Inheritors Conrad clarifies what he and Ford were trying to do:

Judge them as we may, the spirit of tradition and the body of achievement are the very spirit and the very body not only of any single race, but of the entire mankind, which, without the vast breadth and colossal form of the past would be resolved into a handful of the dying, struggling feebly in the darkness under an overwhelming multitude of the dead. (Letters 2: 347-8)

In an eloquent acknowledgement of the legacy the future inherits from the past, Conrad continues: "Thus our Etchingham Granger, when in the solitude that falls upon his soul, he sees the form of the approaching Nemesis, is made to understand that no man is permitted 'to throw away with impunity the treasure of his past - the 
past of his kind—whence springs the promise of his future"” (Letters 2: 348). The letter is a long and impassioned expression of Conrad and Ford's vision in The Inheritors, and in many ways it is an optimistic affirmation of humanity's essential contradictions, contradictions which, for Conrad, make utopias of the type that Wells was beginning to advocate, impossible. ${ }^{20}$

By contrast, as the new century unfolded, Wells advocated dispensing with the Victorian past and embracing a future in which humanity could attain to heights as yet unimagined because unleashed from the fetters of history and tradition. In A Modern Utopia (1905), the narrator, a cypher for Wells, is described as "always talking as though you could kick the past to pieces; as though one could get right out from oneself and begin afresh" (359). Dispensing with what Wells viewed as the stranglehold of tradition is a theme common to his speculative works postAnticipations - he felt it was a way of enabling radical change. It was also another symptom of the widening gulf between Wells and Conrad, and the crux of their opposing views of history and the future as laid out in Anticipations and The

\section{Inheritors.}

\section{Conclusion}

The intimate literary relations between Conrad, Ford and Wells inevitably brings into focus the cross currents in their respective works. For example, when the woman in The Inheritors "prophesied a reign of terror for us" Conrad and Ford deliberately echo Wells's invisible man, Griffin, who, as he becomes increasingly embattled and paranoid, announces his intention to declare war on the small county town of Burdock and "establish a Reign of Terror"; and all three authors are, of course, conscious of references to the horrors of the French Revolution to which this phrase refers (The 
Inheritors 12; Invisible Man 229). Even closer, in historical terms, Conrad, in particular, had experienced at first hand the terror and the horrors perpetrated by the Belgians in the Congo.

Possibly, when they wrote The Inheritors and invoked and challenged ideas and themes from their discussions with Wells, the collaborators were hopeful that their influential neighbor and friend would be engaged with and stimulated by the debate that they provoked: nothing could have been further from the truth. In a letter to the editor of the English Review in the summer of 1920, Wells took the opportunity to outline his objections to Conrad and Ford's collaborations, concluding: "That dead, witless book, 'The Inheritors', justifies my warnings. That and a second book, of which I forget the title - it was an entirely stagnant 'adventure' story, festering with fine language — were an abominable waste of Conrad's time and energy" (Correspondence 3: 38). ${ }^{21}$ This and his later lampooning of the novel in The Bulpington of Blup over ten years later prove that his disdain for The Inheritors was enduring. ${ }^{22}$

Conrad and Ford's collaboration on The Inheritors was neither a critical nor a commercial success. Its ironic treatment of political utopianism lacks Wells's deft narrative acuity, and his penetrating satiric touch. In the end, the novel suffers from obtuse arguments, a confusing plot, and frequent wooden and unconvincing dialogue. It does, however, bring to the fore the conflicting response of authors to the radical changes of the emerging Edwardian age, responses that were to become even more polarized as Europe moved inexorably towards the devastating conflagration of the Great War. Conrad and Ford took their lead from Wells in using the chronotope of the fourth dimension to engage in a debate about the possibilities presented by the new century. For Conrad, Ford and Wells potential futures are thus imagined through the 
concept of another dimensional space where the imagination can have free rein to explore what could be without the limitations imposed by the known physical world.

\footnotetext{
${ }^{1}$ This letter is a transcript of an original previously owned by George Lazarus, but now, so far as is known, in other private hands. The only reference available at the time of writing is the following:
} [HGW to JBP, "20 11 01", typed transcription in folder W-P24b, identified as "Laz II 127”]. I am very grateful indeed to Charles Blair at the University of Illinois for bringing this to my attention and for providing the transcript to letter and the one at 3 below. I have discussed this letter and several others between Wells and Pinker in a paper forthcoming in a special edition of Conradiana.

${ }^{2}$ Wells's letter is unpublished and in the H. G. Wells collection at the University of Illinois (Laz II, 117).

${ }^{3}$ Their first collaboration was on Romance (1903), which had been temporarily abandoned over plot difficulties, and proceeded to write The Inheritors which appeared in print before Romance. See Ford, A Personal Remembrance, pp. 117-118.

${ }^{4}$ Mario Curreli briefly discusses the Wellsian influences on the book and deftly demonstrates its debt to other Conrad tales, but gives no sustained discussion of the scientific fantasy elements of the tale.

${ }^{5}$ Laurence Davies has traced the origins of the term "Fourth Dimension" even further back to the mathematical developments of the 1870s, particularly in the work of William Kingdon Clifford (Davies 187-89).

${ }^{6}$ W. T. Stead's "Throughth; Or, on the Eve of the Fourth Dimension" appeared in Review of Reviews 7 in April 1893, p. 426. It is reprinted in Tattersdill, p. 94.

${ }^{7}$ Morris, of course, used the idea in his futurological novel, News From Nowhere (1890), and Wells began his literary career in 1895 with The Time Machine, perhaps the most influential novel to employ the idea of a fourth dimension in time.

${ }^{8}$ Kleiner's article, written in 1973 , is an important and seemingly overlooked contribution to the field of Conrad studies. It will feature prominently in this article by way of bringing it to the attention of those interested in Conrad's experimentation with genre, and with The Inheritors in particular. 
${ }^{9}$ Actually, Wells never wrote a story called "Fear". What Ford is referring to is a short story, "The Red Room", also known as "The Ghost of Fear" written in 1894 and published in 1896. It concerns a supposedly haunted room, and ends with the narrator declaring: "There is Fear in that room of hersblack Fear, and there will be — so long as this house of sin endures" (The Plattner Story and Others 178). Ford wrote one other tale directly inspired by Wells, his 1908 novel, Mr. Apollo, inspired by The Sea Lady (1902), but this is a fantasy rather than a tale inspired and influenced by science.

${ }^{10}$ Cedric Watts is convinced that The Time Machine and The Island of Doctor Moreau (1896) "have left their mark on various Conradian texts, notably 'Heart of Darkness' and The Inheritors'” (62).

${ }^{11}$ The comment about Wells's sales and leadership come from Ford Madox Ford, Mightier than the Sword, pp.154-5.

${ }^{12}$ Romance was originally entitled Seraphina, but the authors changed its title to signal their intention to offer a Stevensonian adventure-romance.

${ }^{13}$ The title of Kleiner's article makes this clear from the start: “Joseph Conrad's Forgotten Role in the Emergence of Science Fiction.”

${ }^{14}$ Although it is not completely clear that in this letter Conrad is referring to The Inheritors, there is no other writing of Ford's, or for that matter Conrad's, at the time that would elicit such a response. I am thus assuming that it is their collaboration that is being referred to, and this is corroborated by Karl and Davies in their footnote to the letter.

${ }^{15}$ W. T. Stead, "Psychic Photography.” Borderland 3, no. 3 (July 1896), p. 317. Reprinted in Tattersdill p. 105

${ }^{16}$ See Dryden, pp. 26-32.

${ }^{17}$ A rather ironic assertion, since Abraham is traditionally the epitome of religious belief.

${ }^{18}$ See Dryden, pp. 10-26.

19. See Dryden pp. 262-67, for a full discussion of The Bulpington of Blup.

${ }^{20}$ This idea of the essential contradictions that lie at the core of humanity is one of Conrad's passionate beliefs, one that defines the ultimate conflict between his view of humanity and that of Wells. See Joseph Conrad and H. G. Wells, Chapter 5, for a fuller discussion of this debate.

${ }^{21}$ The "second" book was, of course, Romance. 
${ }^{22}$ See Joseph Conrad and H. G. Wells, Chapter 6, "The Shape of War and of Things to Come", for more discussion of Wells's response to The Inheritors in The Bulpington of Blup. It is also interesting to note that the Bulpington of the title is in some ways a satire on Ford and his views.

\section{WORKS CITED}

Conrad, Joseph. The Collected Letters of Joseph Conrad, Volume 2, 1898-1902. Frederick R. Karl and Laurence Davies eds. Cambridge University Press, 1986.

:-- Heart of Darkness. Robert Kimbrough ed. W. W. Norton, 1988.

Conrad, Joseph \& Ford Madox Ford, The Inheritors; An Extravagant Story. George Hay, Foreword. David Seed, Introduction. Liverpool University Press, 1999.

Curreli, Mario. “Invading Other People's Territory: The Inheritors.” Conradiana, vol. 37, no. 1-2, 2005, pp. 79-100.

Davies, Rupert Hart. Hugh Walpole: A Biography. Macmillan, 1952.

Davies, Laurence. "Ford's Early Fiction and 'Those Queer Effects of Real Life'." The Edwardian Fiction of Ford Madox Ford. Laura Colombino and Max Saunders eds. Rodopi, 2013, pp. 185-204. Dryden, Linda. Joseph Conrad and H. G. Wells: The Fin de Siècle Literary Scene. Palgrave, 2015.

Ford, Ford Madox. Joseph Conrad: A Personal Remembrance. Duckworth, 1924.

--: Mightier than the Sword. George Allen and Unwin, 1938.

Hampson, Robert. Conrad's Secrets. Palgrave, 2012.

Kleiner, Elaine L. “Joseph Conrad's Forgotten Role in the Emergence of Science Fiction”,

Extrapolation 15, 1973, pp. 25-34.

Saunders, Max. Ford Madox Ford: A Dual Life. Oxford University Press, 1996.

--: "Empire of the Future: The Inheritors, Ford, Liberalism and Imperialism," in The Edwardian Ford Madox Ford, Laura Colombino and Max Saunders eds. Rodopi 2013.

Sherborne, Michael, H. G. Wells: Another Kind of Life. Peter Owen, 2010.

Tattersdill, Will. Science, Fiction, and the Fin-de-Siècle Periodical Press. Cambridge University Press, 2016.

Wagar, W. Warren. H.G. Wells: Traversing Time. Wesleyan University Press, 2004.

Watts, Cedric. Joseph Conrad: A Literary Life. Palgrave Macmillan, 1989. 
Wells, H. G. An Experiment in Autobiography: Discoveries and Conclusions of a Very Ordinary Brain Vol. II. Faber \& Faber, 1934.

--: A Modern Utopia. Chapman and Hall, 1905.

--: Correspondence of H. G. Wells. Vol. 1. David C. Smith ed. Pickering \& Chatto, 1998.

--: Correspondence of H. G. Wells. Vol. 3. David C. Smith ed. Pickering \& Chatto, 1998.

--: The Discovery of the Future: A Discourse Delivered to the Royal Institute on January 24, 1902. T.

Fisher Unwin, 1902.

--: The Food of the Gods, and How it came to Earth. Macmillan, 1904,

--: The Invisible Man: A Grotesque Romance. Harper \& Brothers, 1897.

--: The Plattner Story and Others. Methuen \& Co., 1897.

--: The Time Machine: An Invention. Henry Holt, 1895.

--: The War of the Worlds. William Heinemann, 1898. 